\title{
Reproductive biology of the Neotropical electric fish Brachyhypopomus draco (Teleostei: Hypopomidae) from southern Brazil
}

\author{
Andrea B. Schaan, Júlia Giora and Clarice B. Fialho
}

The reproductive biology of a population of the weakly electric fish Brachyhypopomus draco from southern Brazil is described. Information is provided on the establishment of the reproductive period in this species and its relations with environmental and feeding factors, as well as on the absolute and relative fecundities, spawning type, sex ratio and sexual dimorphism. The species exhibits a relatively long reproductive period, a relative fecundity of 0.173 oocytes per $\mathrm{mg}$ of female total weight, and fractional spawning. The sex ratio did not differ from 1:1 during all sampled months. Sexual dimorphism related to hypertrophy of the male's distal portion of caudal filament was observed and males grew to greater lengths than females. Male gonadosomatic index (GSI) was significantly related to water depth, oxygen saturation and temperature. Female GSI was significantly related to water depth and hepatosomatic index.

Descreve-se a biologia reprodutiva de uma população do peixe elétrico Brachyhypopomus draco do sul do Brasil. São apresentadas informações a respeito do período reprodutivo estabelecido e suas relações com fatores ambientais e alimentares, bem como a fecundidade absoluta e relativa, tipo de desova, proporção sexual e dimorfismo sexual. A espécie apresentou um período reprodutivo relativamente longo, uma fecundidade relativa de 0,173 ovócitos por mg de peso total da fêmea e uma desova do tipo parcelada. A proporção sexual encontrada foi de 1:1 durante todos os meses amostrados. Dimorfismo sexual relacionado com a hipertrofia da porção distal do filamento caudal dos machos e com o tamanho total dos espécimes - machos atingindo tamanhos maiores do que as fêmeas - foi encontrado. O IGS dos machos foi significativamente relacionado com a profundidade da água, a saturação de oxigênio e a temperatura; o IGS das fêmeas foi significativamente relacionado com a profundidade da água e o índice hepatossomático.

Key words: Reproduction, Gymnotiformes, Abiotic factors, Laguna dos Patos system, Parque Estadual de Itapuã.

\section{Introduction}

The order Gymnotiformes is restricted to Neotropical freshwaters, occurring from southern Mexico to Argentina, and to the Caribbean island of Trinidad (Mago-Leccia, 1978; Crampton \& Albert, 2006). Representatives of this order can be found in several aquatic habitats, including river channels, floodplains, flooded forests, forest streams, waterfalls, swamps, coastal creeks and estuarine reaches (Crampton \& Albert, 2006). The family Hypopomidae is known from the continental waters of all South American countries except Chile, ranging from río de La Plata in Argentina to rio Tuira in Panama (Albert, 2001). The genus Brachyhypopomus is the most widely distributed among the hypopomids, reaching the same geographic limits as the family (Albert \& Crampton, 2003).
Reproduction represents one of the most important aspects of the biology of a species, the maintenance of viable populations depending on its success (Suzuki \& Agostinho, 1997). Although studies on the reproductive cycle of fishes have been extensively conducted world-wide, Neotropical region has received much less attention (Barbieri \& Barbieri, 1985). For gymnotiform species, few data concerning reproductive aspects are available (Kirschbaum, 1979; Barbieri \& Barbieri, 1982, 1983a, 1983b, 1984a, 1984b, 1985; Hagedorn, 1988; Assunção \& Schwassmann, 1995; Kirschbaum \& Schugardt, 2002; Silva et al., 2003; Quintana et al., 2004). In southern Brazil, studies on the reproductive biology of gymnotiform species have been undertaken by Cognato \& Fialho (2006) on Gymnotus aff. carapo, by Giora \& Fialho (2009) concerning Eigenmannia trilineata, and by Giora (2008)

Laboratório de Ictiologia, Departamento de Zoologia, Universidade Federal do Rio Grande do Sul. Av. Bento Gonçalves, 9500 , Prédio 43435, 91501-970 Porto Alegre, RS, Brazil. andreabrandelli@gmail.com (ABS), jugiora@hotmail.com (JG), cbfialho@pro.via-rs.com.br (CBF) 
concerning two Brachyhypopomus species, all in the protected area of Parque Estadual de Itapuã.

The aim of this study was to characterize the reproductive biology of a population of Brachyhypopomus draco, recently described by Giora et al. (2008), from southern Brazil by determining the reproductive period and its relations with environmental and feeding factors, and to determine the absolute and relative fecundities, spawning type, sex ratio and sexual dimorphism of the species.

\section{Material and Methods}

The specimens of Brachyhypopomus draco were sampled monthly from September 2003 to August 2004 in lagoa Verde, in the Parque Estadual de Itapuã (Rio Grande do Sul State), which is situated in the laguna dos Patos system. Lagoa Verde $\left(30^{\circ} 22^{\prime} 52^{\prime \prime} \mathrm{S} 51^{\circ} 01^{\prime} 25^{\prime \prime} \mathrm{W}\right)$ has an area of approximately 4 ha and a maximum depth of $1 \mathrm{~m}$. The site shows a predominantly muddy substratum, great amount of floating plants and plant material in decomposition.

Fishes were sampled using a dip net under floating vegetation and an electric fish finder (Crampton et al., 2007). The specimens were fixed in the field in $10 \%$ formalin solution. Water temperature, depth, conductivity, and dissolved oxygen were recorded at the time and place of collection. Rainfall data were obtained from the Meteorology District of Porto Alegre and photoperiod was obtained with the SkyMap Pro 9.0 software , by correlating dates of collection with collecting place coordinates.

In the laboratory, fishes were preserved in $70 \%$ ethanol. Total length (Lt) in millimeters and total weight $(\mathrm{Wt})$ in grams were measured, and the specimens were dissected to record liver (Wl), stomach (Ws) and gonad (Wg) weight. Voucher specimens are deposited in the fish collection of the Departamento de Zoologia, Universidade Federal do Rio Grande do Sul, Porto Alegre, Brazil (UFRGS 5719 and UFRGS 6635).

Stomach repletion index (RI), hepatosomatic index (HSI) and gonadosomatic index (GSI) were estimated following the formula adapted from Santos (1978). These indexes represent the proportion of organ weight to total individual weight: RI $=100 \mathrm{x} \mathrm{Ws} / \mathrm{Wt} ; \mathrm{HSI}=100 \mathrm{x} \mathrm{Wl} / \mathrm{Wt}$; and GSI $=100 \mathrm{x} \mathrm{Wg} /$ $\mathrm{Wt}$. Ws corresponds to stomach weight, Wl to liver weight, $\mathrm{Wg}$ to gonadal weight and $\mathrm{Wt}$ to total weight.

The reproductive period for males and females was established through the analysis of monthly variation of mean GSI values. A multiple regression with analysis of variance (ANOVA) (Zar, 1999) was applied to investigate relations between abiotic factors (rainfall, photoperiod, temperature, conductivity, depth, and oxygen saturation) and GSI, as well as between feeding factors (RI and HSI) and GSI. To avoid tendentious results in the multiple regression analysis, a test of correlation was applied to the abiotic and feeding factors tested, which showed no correlation between them.

Absolute fecundity was estimated by counting all vitellogenic oocytes present in the ovaries of 10 females with the highest GSI values. The relative fecundity was determined by the number of vitellogenic oocytes counted per female milligram of total weight (Adebisi, 1987). For the determination of the spawning type, the same gonads selected for fecundity analysis were used. A sub-sample of 150 oocytes was removed from each selected gonad and the largest possible oocyte diameter was obtained by examination under a stereomicroscope equipped with an ocular micrometer (Vazzoler, 1996).

The sex ratio was determined by the distribution of male and female frequency during the sample period. The $\mathrm{c}^{2}$ test (with a confidence limit of $\mathrm{p}<0.01$ ) was applied to determine the existence of significant differences between the number of males and females. The distribution of relative frequencies of males and females in different total length classes was analyzed to observe sexual dimorphism related to total length.

The distal portion of the caudal filament of some males was vertically broadened and laterally compressed. To determine a possible relation between this sexually dimorphic feature and the established reproductive period, the greatest depth found in the last $15 \mathrm{~mm}$ of the filament was measured, and its percentage in relation to the total length was calculated in every male sampled. These values were grouped in modification classes (level one, from 0 to $1.5 \%$; level two, from $1.51 \%$ to $2.5 \%$; level three, from $2.51 \%$ to $3.5 \%$ ) and their relative frequencies were analyzed monthly by a $\chi^{2}$ test (with a confidence limit of $p<0.05$ ). Individuals with indications of predation or regeneration were excluded from this analysis.

\section{Results}

A total of 300 specimens - 150 females with total length ranging from 55.5 to $176.8 \mathrm{~mm}$ and 150 males ranging from 68.2 to $212.3 \mathrm{~mm}$ - were analyzed. The estimated reproductive period lasted from August to December for females and from July to December for males (Fig. 1).

The GSI of B. draco males did not exhibit a significant relation with the feeding indexes analyzed (IR and HSI), whereas the GSI of females showed significant positive relation with HSI (Table 1). Among the six abiotic factors that were considered, temperature, oxygen saturation, and water depth positively influenced male GSI, while female GSI was affected only by water depth (Table 1). Monthly data of RI and HSI variation are presented in Figs. 2 and 3 respectively. Monthly data of water temperature, conductivity, depth, dissolved oxygen, rainfall, and photoperiod for the study site are summarized in Fig. 4.

The absolute fecundity of the species analyzed showed an average value of 935.8 vitellogenic oocytes (ranging from 576 to 1391 oocytes) for females with total length from 113.9 to $174 \mathrm{~mm}$ (Table 2). The average relative fecundity was estimated as 0.17 vitellogenic oocytes per mg total weight (Table 2). Analysis of the absolute frequency distribution of oocyte diameter conforms to that of a species with synchronous oocyte development in more than two groups, and with fractional spawning, the species being estimated to spawn at least twice during a reproductive period (Fig. 5). A 


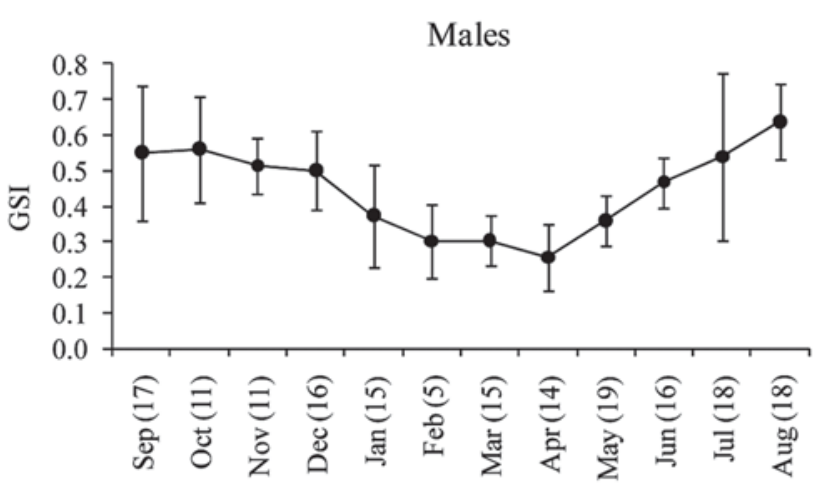

Females

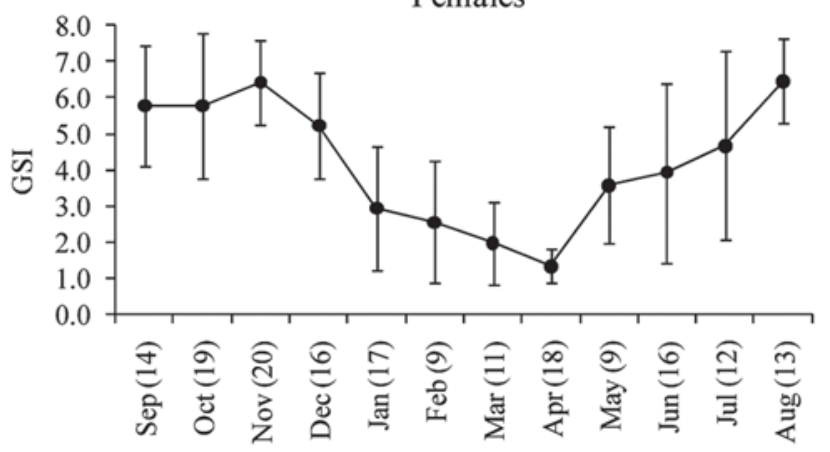

Fig. 1. Monthly variation of mean gonadosomatic index (GSI) for Brachyhypopomus draco males (above) and females (below) from September 2003 to August 2004. Vertical bars represent the standard deviation and the values between the brackets are the sample size.

Table 1. Multiple regression with analysis of variance (ANOVA) of gonadosomatic index (GSI) and hepatosomatic index (HSI) for Brachyhypopomus draco females sampled from September 2003 to August 2004. Only significant predictor variables are shown presented.

\begin{tabular}{lcccccccc}
\hline $\begin{array}{l}\text { Dependent variable }=\mathrm{GSI} \\
\text { Predictor variables }\end{array}$ & $\mathrm{F}$ & $\mathrm{R}$ & $\mathrm{R} 2$ & Coefficient & $\mathrm{SE}$ & $\mathrm{t}$ & $\mathrm{p}$ \\
\hline Females & & & & & & & & \\
$\quad \mathrm{HSI}$ & 16.615 & 0.79 & 0.624 & 3.579 & 0.878 & 4.076 & 0.002 \\
Depth (cm) & 25.379 & 0.847 & 0.717 & 0.146 & 0.029 & 5.038 & 0.001 \\
Males & & & & & & & \\
$\quad$ Depth (cm) & 23.307 & 0.837 & 0.7 & 0.008 & 0.001 & 6.469 & $<0.000$ \\
$\mathrm{O}_{2}(\%)$ & 24.401 & 0.919 & 0.844 & 0.003 & 0.001 & 5.405 & 0.001 \\
Temp. $\mathrm{H}_{2} \mathrm{O}\left({ }^{\circ} \mathrm{C}\right)$ & 40.710 & 0.969 & 0.939 & 0.01 & 0.003 & 3.502 & 0.008 \\
\hline
\end{tabular}

high frequency of pre-vitellogenic (reserve) oocytes can be observed. These are the smallest germinative cells that are visible under a stereomicroscope, have a large and central nucleus, and contain no yolk vesicles. The reserve oocytes will only mature in the next reproductive period, but are followed by oocyte stores in successive maturation stages (Fig. 5), which are released at different times in the current reproductive period. The presence of reserve oocytes and more than one store of oocytes in successive developmental stages provide evidence that $B$. draco is an iteroparous species.
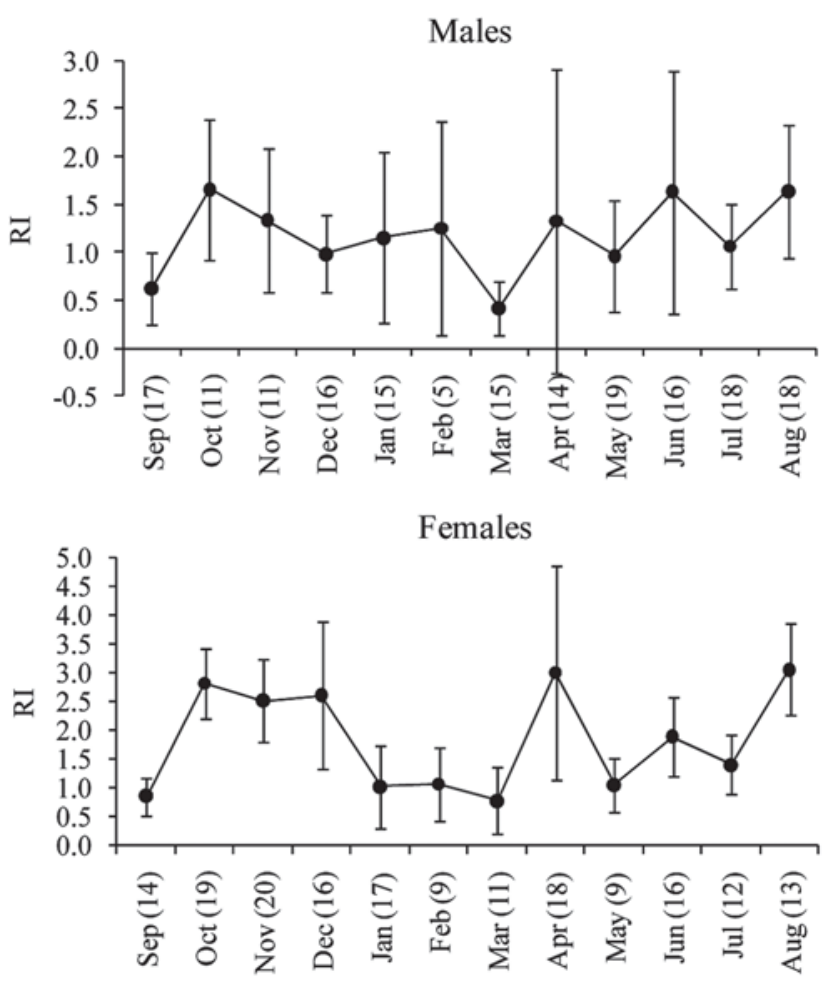

Fig. 2. Monthly variation of mean repletion index (RI) for Brachyhypopomus draco males (above) and females (below) from September 2003 to August 2004. Vertical bars represent the standard deviation and the values between the brackets are the sample size.

The sex ratio established for the $B$. draco studied population was 1:1 in each month, as well as in the global sample. Sexual dimorphism related to total body length was determined for the species, with males growing to greater lengths than females (Fig. 6). The largest male and female sampled had total lengths of $212.3 \mathrm{~mm}$ and $176.8 \mathrm{~mm}$, respectively. Males of $B$. draco with hypertrophy of the distal portion of caudal filament - vertical broadening and lateral compression, which give the caudal filament a paddle-like shape - were sampled during all months of the year, with male caudal filament depth ranging from 0.96 to $6.88 \mathrm{~mm}$, representing $1.14 \%$ to $3.47 \%$ of total length. Caudal filaments grouped in level one ( $n=32)$ were found in all months of the year, except November and December, but with higher frequency in April and July (Fig. 7). Caudal filaments in level two $(n=94)$ were found in all sampled months, showing a higher frequency in November (Fig. 7). Filaments in level three $(\mathrm{n}=7)$ were found from August to January except in September and November (Fig. 7). The $\chi^{2}$ test indicated a significant difference between the three levels during the whole sampled year, except in February and July, with the highest values occurring from August to December and in March (Table 3). No individuals with level three filaments were found from February to July of the year studied, suggesting a regression of the caudal filament hypertrophy after the reproductive period months (Fig. 7). 

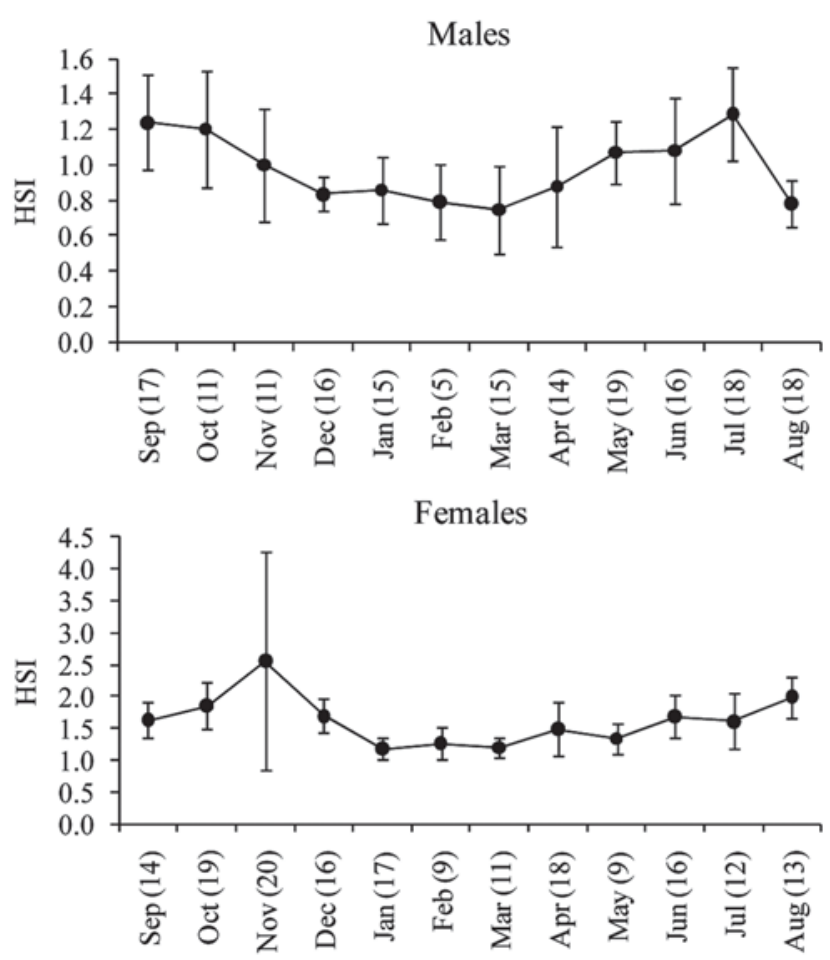

Fig. 3. Monthly variation of mean hepatosomatic index (HSI) for Brachyhypopomus draco males (above) and females (below) from September 2003 to August 2004. Vertical bars represent the standard deviation and the values between the brackets are the sample size.

\section{Discussion}

Reproductive processes in fishes are controlled by endogenous and exogenous aspects; endogenous aspects being represented by hormonal metabolism and exogenous by environmental characters, which are seasonally variable (Jobling, 1995). Fish species need particular environmental conditions during the reproductive period to guarantee the growth and survival of new generation individuals (Vazzoler, 1996). Brachyhypopomus draco has a seasonal reproductive period occurring from August to December for females and from July to December for males, periods that corresponds to the middle of winter till the end of spring in the subtropical southern hemisphere.

The reproductive cycles of gymnotiform species from the tropical area of the Neotropical region have been related to environmental aspects involved in the changes between rainy and dry seasons, where breeding occurs when the increase in rainfall determines high water levels and low water conductivities (Hopkins, 1974a, 1974b; Kirschbaum, 1975, 1979, 1984, 2000; Schwassmann, 1976; Hagedorn, 1988; Kirschbaum \& Schugardt, 2002). On the other hand, studies with gymnotiform species, in regions close to the southern boundary of their continental distribution, show the relation of reproductive periods with the increase in temperature
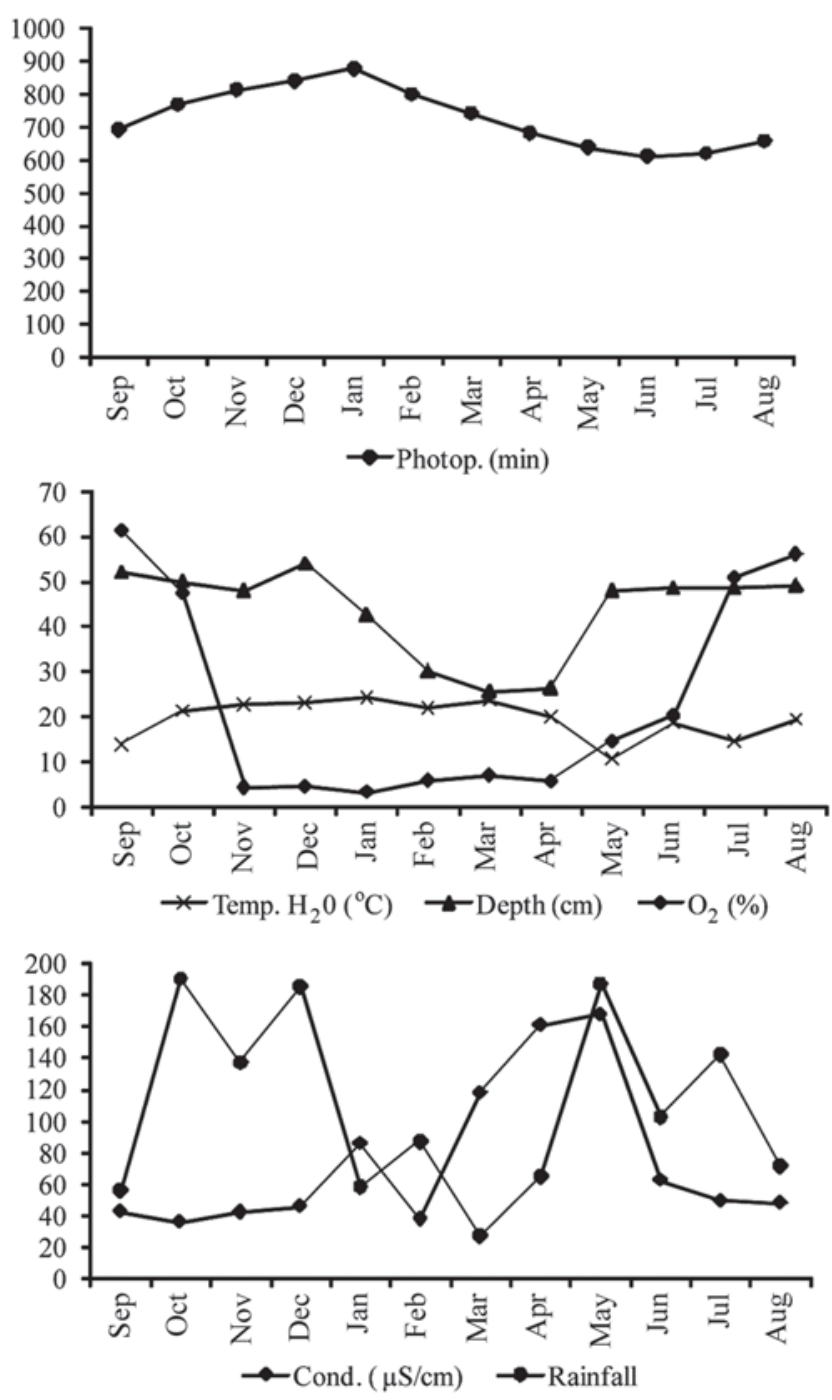

Fig. 4. Monthly variation of light photoperiod (min) (above); water temperature $\left({ }^{\circ} \mathrm{C}\right)$, depth $(\mathrm{cm})$ and oxygen saturation (\%) (middle); conductivity $(\mu \mathrm{S} / \mathrm{cm})$ and rainfall $(\mathrm{mm})$ (below). Values in lagoa Verde from September 2003 to August 2004.

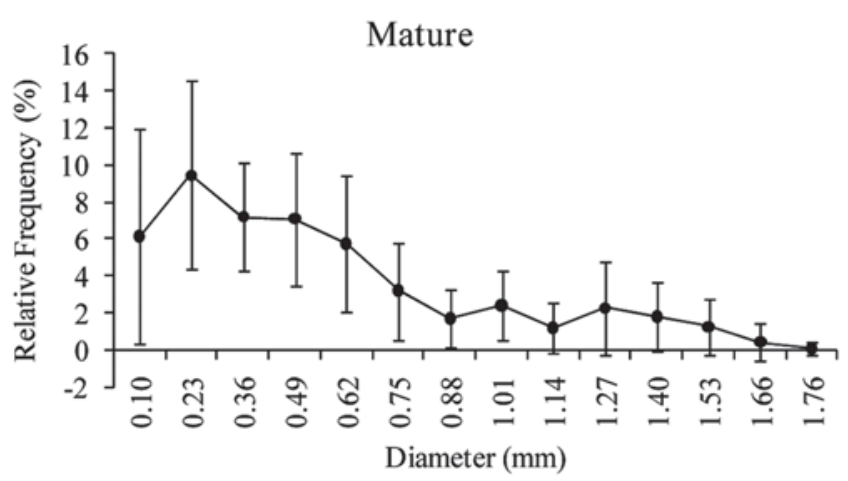

Fig. 5. Distribution of relative frequency of 150 oocyte diameters of 10 Brachyhypopomus draco females with highest GSI values sampled from September 2003 to August 2004. Vertical bars represent the standard deviation. 
Table 2. Gonadosomatic index (GSI), total length (Lt), total weight (Wt), absolute fecundity (AF) and relative fecundity (RF) of 10 Brachyhypopomus draco females.

\begin{tabular}{lccccc}
\hline & GSI & Lt & Wt & AF & RF \\
\hline & 7.28 & 117.1 & 3.5 & 764 & 0.22 \\
& 7.36 & 174.0 & 8.8 & 679 & 0.07 \\
& 7.55 & 161.2 & 6.8 & 1154 & 0.17 \\
& 7.61 & 172.9 & 7.8 & 1140 & 0.15 \\
& 7.82 & 113.9 & 2.8 & 576 & 0.21 \\
& 8.00 & 156.2 & 7.8 & 783 & 0.10 \\
& 8.28 & 163.7 & 8.4 & 715 & 0.08 \\
& 8.54 & 121.8 & 3.2 & 1087 & 0.34 \\
& 8.98 & 139.4 & 5.7 & 1391 & 0.24 \\
& 9.20 & 161.0 & 7.1 & 1069 & 0.15 \\
\hline Average & & & & 935.8 & 0.173 \\
Standard Deviation & & & & 265.44 & 0.083 \\
\hline
\end{tabular}

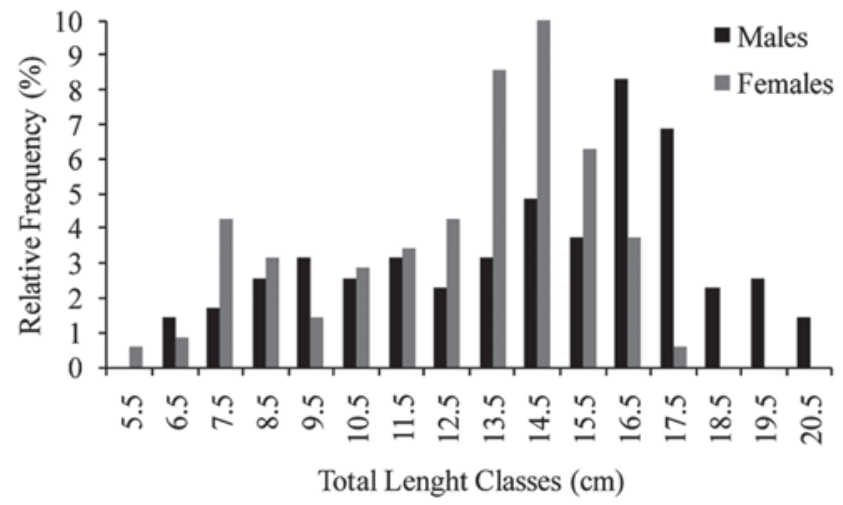

Fig. 6. Relative frequency distribution of Brachyhypopomus draco males $(n=175)$ and females $(n=175)$ for total length classes sampled from September 2003 to August 2004.

(Silva et al., 1999; Ardanaz et al., 2001; Silva et al., 2002; Quintana et al., 2004), in photoperiod (Giora \& Fialho, 2009) or in both temperature and photoperiod (Silva et al., 2003; Cognato \& Fialho, 2006). For the B. draco population from lagoa Verde, the male reproductive cycle showed a positive relation with temperature, but no relation was found for photoperiod.

For the B. draco population studied, male and female reproductive periods were related to water depth, male reproductive period being also related to oxygen saturation. These mentioned abiotic factors are linked to environmental changes caused by rainfall suggesting that breeding occurs during the rainiest period of the year. However, the rainfall data obtained for the study area did not show a statistically significant relation with male and female reproductive periods. Studies at Parque Estadual de Itapuã concerning gymnotiform species have established reproductive periods occurring from October to February for Eigenmannia trilineata (Giora \& Fialho, 2009) and from November to March for Gymnotus aff. carapo (Cognato \& Fialho, 2006). With this mind, the low rainfall rates and water depth observed during the months of
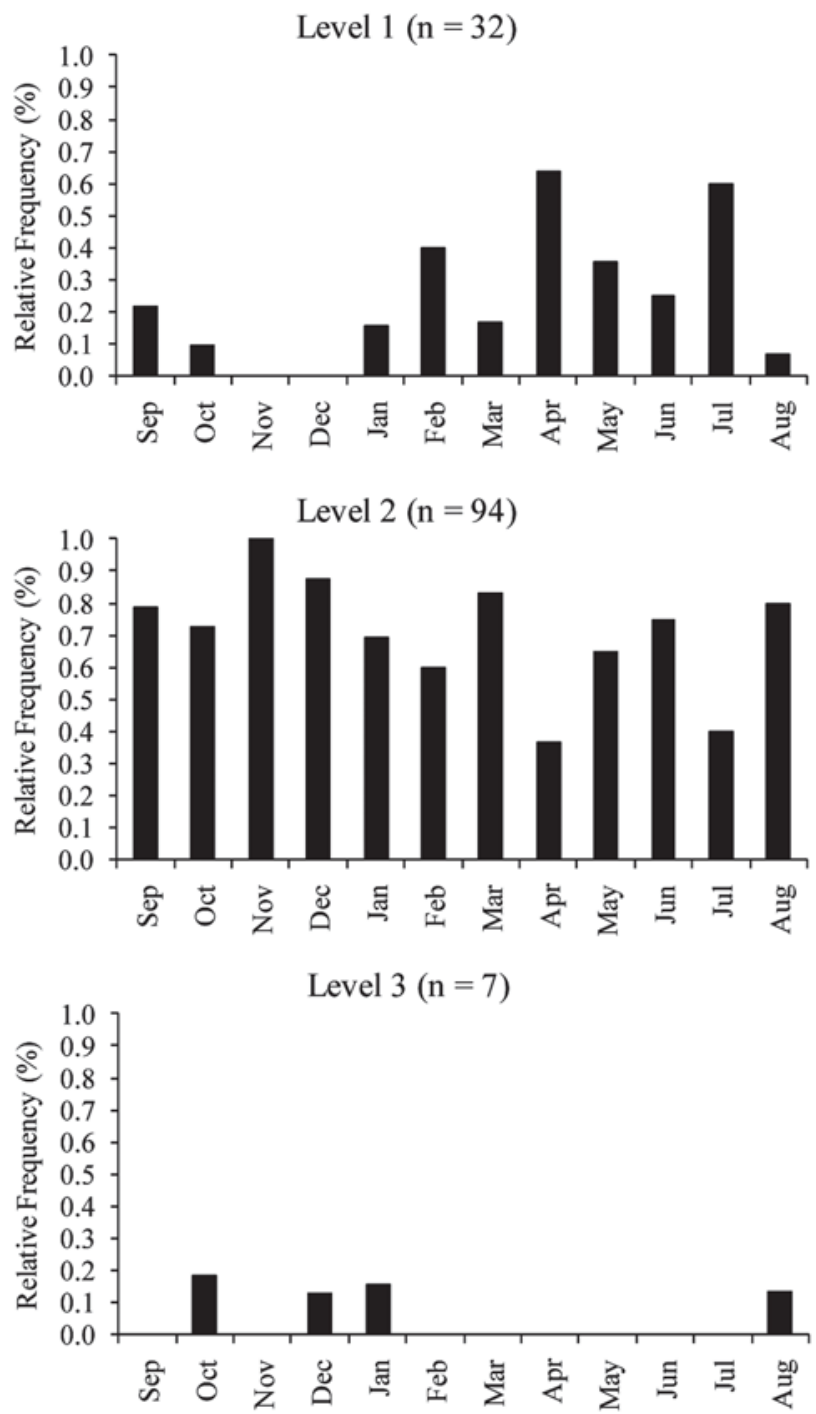

Fig. 7. Relative frequency distribution of caudal filament depth levels for Brachyhypopomus draco males. Caudal filaments depth Level 1 = from 0 to $1.5 \%$; Level 2 = from $1.51 \%$ to $2.5 \%$; Level $3=$ from $2.51 \%$ to $3.50 \%$.

Table 3. Chi-square test $\left(\chi^{2}\right)$ for caudal filament modification levels of Brachyhypopomus draco males sampled from September 2003 to August $2004(\mathrm{p}<0.05$; df = 2).

\begin{tabular}{ccc}
\hline Month & $\mathrm{n}$ & $\chi^{2}$ \\
\hline Sep & 14 & 13.86 \\
Oct & 11 & 7.82 \\
Nov & 9 & 18.00 \\
Dec & 8 & 10.75 \\
Jan & 13 & 7.54 \\
Feb & 5 & 2.80 \\
Mar & 12 & 14.00 \\
Apr & 11 & 6.73 \\
May & 17 & 10.71 \\
Jun & 8 & 7.00 \\
Jul & 10 & 5.60 \\
Aug & 15 & 28.67 \\
$\Sigma$ & 133 & 133.46 \\
\hline
\end{tabular}


January through April of the year studied might have induced the regression of male and female gonads and might have determined the anticipation of the end of the $B$. draco population breeding season.

The number of reproductive episodes before death is a key life-history character, and biologists have long considered the distinctions between life histories with a single reproductive episode (semelparity) and those with multiple episodes (iteroparity) to be particularly important (Young, 1981). The B. draco population studied showed an iteroparous life-history strategy, agreeing with the results that have been obtained for other species of Gymnotiformes (Barbieri \& Barbieri, 1982; Assunção \& Schwassmann, 1995; Kirschbaum \& Schugardt, 2002; Quintana et al., 2004; Cognato \& Fialho, 2006; Giora \& Fialho, 2009; Giora, 2008).

Iteroparous species of fishes frequently show a negative relation between female HSI and GSI due to the allocation of energy from the liver to the oocytes that are being produced (Jobling, 1995). However, for B. draco females a positive relation between these indexes has been established. Marked differences in fecundity between species often reflect different reproductive strategies; within a given species, fecundity can vary as a result of different adaptation to environmental habitats (Wooton, 1984). The absolute and relative fecundities established for B. draco are slightly lower than those determined for the species Brachyhypopomus bombilla and Brachyhypopomus gauderio (Giora, 2008), which were found to be 587.33 oocytes and 0.21 oocytes per $\mathrm{mg}$ of total weight, and 589.44 oocytes and 0.20 oocytes per $\mathrm{mg}$ of total weight, respectively. Two other studies with Gymnotiformes from southern Brazil have shown slightly higher relative fecundities for the species, these being 0.20 oocytes per mg of total weight for Gymnotus aff. carapo (Cognato \& Fialho, 2006) and 0.27 for E. trilineata (Giora \& Fialho, 2009). According to Vazzoler (1996), fecundity depends, as a last resort, on the coelomatic cavity capacity of lodge ripe oocytes and of oocyte size. As a consequence of the peculiar anatomy of gymnotiform fishes, which results in a short coelomatic cavity that cannot lodge a great number of oocytes, a lower relative fecundity is expected in comparison with Characiformes and Siluriformes species (Cognato \& Fialho, 2006). Notwithstanding, more studies concerning relative fecundity data are needed for a better comparison among species of Gymnotiformes and between these and nongymnotiform fishes.

Considering that fecundity depends on fish total length, fractional spawning represents a procedure through which species can increase the number of oocytes produced during one reproductive season to a much higher number than that predicted considering their size (Vazzoler, 1996). The gymnotiform short coelomatic cavity and relatively low fecundity can be the determinants for the establishment of a fractional spawning reproductive strategy by these fishes, as a way of increasing the amount of oocytes released throughout the reproductive period. Fractional spawning has also been reported as the strategy adopted by all gymnotiform species studied up until now (Barbieri \& Barbieri, 1982; Assunção \& Schwassmann, 1995; Kirschbaum \& Schugardt, 2002; Quintana et al., 2004; Cognato \& Fialho, 2006; Giora \& Fialho, 2009; Giora, 2008).

Sexual dimorphism is a common phenomenon, and there is a great variety of ecological reasons for its origin and maintenance, such as sexual selection and differentiation of reproductive roles (Cox-Fernandes, 1998). Brachyhypopomus draco showed sexual dimorphism related to fish total length with males growing to greater lengths than females - as well as being related to morphology of the caudal filament, which carries the electric organ. Comparing the monthly variation of male GSI and the frequency distribution of caudal filament depth levels, it is possible to conclude that mature males undergo hypertrophy of the distal portion of caudal filament during the reproductive period, after which this structure regresses until the caudal filament resembles that of females and juveniles. This was also corroborated by the $\chi^{2}$ statistical test, with modification levels appearing to be significantly different during almost all the year sampled, especially in the reproductive period, showing no significant differences during the month before and after the reproductive period established, when fishes are probably going through the major modifications of the caudal filament. Modifications in the mature male caudal filament, e.g., broadening, compression, and/or elongation, have been frequently reported for Brachyhypopomus species (Hagedorn \& Carr, 1985; Hagedorn, 1988; Hopkins et al., 1990; Rapp-Py-Daniel \& CoxFernandes, 2005; Giora, 2008). According to Hopkins (1999), for pulse fishes such as Brachyhypopomus, the energy expenditure of electric sign increases with the power and duration of a single EOD generated. Besides that, the same author stated that males that generate longer-duration EODs suffer a drop in the peak amplitude of the discharge, compensating for this drop by growing their tails longer and thicker, so that they can generate greater voltage and current. With this mind, females would choose males for mating on the basis of EODs that have demanding more energy for males to produce, favoring the males with hypertrophy of the distal portion of caudal filament.

\section{Acknowledgements}

We are grateful to Diego de Paula Cognato for the collection of the specimens and to Conselho Nacional de Desenvolvimento Científico e Tecnológico - CNPq. Brazil (process 476821/2003-7; 478002/2006-8).

\section{Literature Cited}

Adebisi, A. A. 1987. The relationships between fecundities, gonadosomatic indices and egg sizes of some fishes of Ogun River, Nigeria. Archiv fuer Hydrobiologie, 111(1): 151-156.

Albert, J. S. 2001. Species diversity and phylogenetic systematics of American knifefishes (Gymnotiformes, Teleostei). Miscellaneous Publications of the Museum of Zoology, University of Michigan, 190: 1-127. 
Albert, J. S. \& W. Crampton. 2003. Family Hypopomidae (Bluntnose Knifefishes) In: Reis, R. E., S. O. Kullander \& C. J. Ferraris Jr. (Eds.). 2003. Check List of Freshwater Fishes of the South and Central America. Porto Alegre, Edipucrs, 742p.

Ardanaz, J. L., A. Silva \& O. Macadar. 2001. Temperature sensitivity of the electric organ discharge waveform in Gymnotus carapo. Journal of Comparative Physiology A, 187: 853-864.

Assunção, M. I. S. \& H. O. Schwassmann. 1995. Reproduction and larval development of Electrophorus electricus on Marajó Island (Pará, Brazil). Ichthyology Exploration of Freshwaters, 6(2): 175-184.

Barbieri, G. \& M. C. Barbieri. 1982. Fecundidade e tipo de desova de Gymnotus carapo (Linnaeus, 1758), na represa do Lobo, Estado de São Paulo (Pisces, Gymnotidae). Spectrum: Jornal Brasileiro de Ciência, 2(7): 25-29.

Barbieri, G. \& M. C. Barbieri. 1983a. Dinâmica da reprodução de Gymnotus carapo na represa do Lobo, Estado de São Paulo. Influência de fatores abióticos. (Pisces, Gymnotidae). Tropical Ecology, 24(2): 244-259.

Barbieri, G. \& M. C. Barbieri. 1983b. Growth and first sexual maturation size of Gymnotus carapo (Linnaeus, 1758) in the Lobo reservoir (state of São Paulo, Brazil) (Pisces, Gymnotidae). Revue d'Hydrobiologie Tropicale, 16(2): 195-201.

Barbieri, M. C. \& G. Barbieri. 1984a. Reprodução de Gymnotus carapo (Linnaeus, 1758) na represa do Lobo (SP.). Morfologia e histologia de testículos. Variação sazonal. (Pisces, Gymnotidae). Revista Brasileira de Biologia, 44(2): 141-148.

Barbieri, G. \& M. C. Barbieri. 1984b. Crescimento de Gymnotus carapo (Linnaeus, 1758) na represa do Lobo, Estado de São Paulo, pelo método da distribuição da freqüência de comprimento (Pisces, Gymnotidae). Revista Brasileira de Biologia, 44(3): 239-246.

Barbieri, M. C. \& G. Barbieri. 1985. Reprodução de Gymnotus carapo (Linnaeus, 1758) na represa do Lobo (SP). Morfologia e histologia de ovário. Variação sazonal. (Teleostei, Gymnotidae). Revista Brasileira de Biologia, 45(1/2): 3-12.

Cognato, D. de P. \& C. B. Fialho. 2006. Reproductive biology of a population of Gymnotus aff. carapo (Teleostei: Gymnotidae) from southern Brazil. Neotropical Ichthyology, 4(3): 339-348.

Crampton, W. G. R. 1998. Effects of anoxia on the distribution, respiratory strategies and electric diversity of gymnotiform fishes. Journal of Fish Biology, 53(A): 307-330.

Crampton, W. G. R. \& J. S. Albert. 2006. Evolution of electric signal diversity in gymnotiform fishes. I. Phylogenetic systematics, ecology and biogeography. Pp. 647-696 and 718731. In: Ladich, F., S. P. Collin, P. Moller \& B. G Kapoor (Eds.). Communication in Fishes. Enfield, Science Publishers, 870p.

Crampton, W. G. R., J. K. Wells, C. Smyth \& S. A. Walz. 2007. Design and construction of an Electric Fish Finder. Neotropical Ichthyology, 5(3): 425-428.

Cox-Fernandes, C. 1998. Sex-related morphological variation in two species of Apteronotid fishes (Gymnotiformes) from the Amazon River Basin. Copeia, 1998(3): 730-735.

Giora, J. 2008. Análise comparada de caracteres reprodutivos e diversidade do gênero Brachyhypopomus Mago-Leccia, 1994 no Rio Grande do Sul. Unpublished Ph.D. Dissertation, Universidade Federal do Rio Grande do Sul, Porto Alegre, 207p.

Giora, J. \& C. B. Fialho. 2009. Reproductive biology of weakly electric fish Eigenmannia trilineata López \& Castello, 1966 (Teleostei, Sternopygidae). Brazilian Archives of Biology and Technology, 52(3): 617-628.
Giora, J., L. R. Malabarba \& W. G. R. Crampton. 2008. Brachyhypopomus draco, a new sexually dimorphic species of Neotropical electric fish from southern South America (Gymnotiformes: Hypopomidae). Neotropical Ichthyology, 6(2): 159-168.

Hagedorn, M. 1988. Ecology and behavior of a pulse-type electric fish, Hypopomus occidentalis (Gymnotiformes, Hypopomidae), in a fresh-water stream in Panama. Copeia, 1988(2): 324-335.

Hagedorn, M. \& E. Carr. 1985. Single electrocytes produce a sexually dimorphic signal in South American electric fish. Journal of Comparative Physiology, 156: 511-523.

Hopkins, C. D. 1974a. Electric communication: functions in the social behavior of Eigenmannia virescens. Behaviour, 50: 270-305.

Hopkins, C. D. 1974b. Electric communication in the reproductive behavior of Sternopygus macrurus (Gymnotoidei). Zeitschrift fur Tierpsychologie, 35: 518-535.

Hopkins, C. D. 1999. Design features for electric communication. Journal of Experimental Biology, 202: 1217-1228.

Hopkins, C. D., N. C. Comfort, J. Bastian \& A. H. Bass. 1990. Functional analysis of sexual dimorphism in an electric fish, Hypopomus pinnicaudatus, Order Gymnotiformes. Brain Behavior and Evolution, 35: 350-367.

Jobling, M. 1995. Environmental biology of fishes. London, Chapman \& Hall, 455p.

Kirschbaum, F. 1975. Environmental factors control the periodical reproduction of tropical electric fish. Experientia, 31: 11591160.

Kirschbaum, F. 1979. Reproduction of the weakly electric fish Eigenmannia virescens (Rhamphichtyidae, Teleostei) in captivity. Behavioral Ecology and Sociobiology, 4: 331-355.

Kirschbaum, F. 1984. Reproduction of weakly electric teleosts: just another example of convergent development? Environmental Biology of Fishes, 10(1/2): 3-14.

Kirschbaum, F. 2000. The breeding of tropical freshwater fishes through experimental variation of exogenous parameters. Breeding through simulation of high and low water conditions. Aquageografia, 20: 95-105.

Kirschbaum, F. \& C. Schugardt. 2002. Reproductive strategies and developmental aspects in mormyrid and gymnotiform fishes. Journal of Physiology - Paris, 96(2002): 557-566.

Mago-Leccia, F. 1978. Los peces de la familia Sternopygidae de Venezuela. Acta Cientifica Venezolana, 29 (Suppl. 1): 1-89.

Quintana, L., A. Silva, N. Berois \& O. Macadar. 2004. Temperature induces gonadal maturation and affects electrophysiological sexual maturity indicators in Brachyhypopomus pinnicaudatus from a temperate climate. The Journal of Experimental Biology, 207: 1843-1853.

Rapp-Py-Daniel, L. H. \& C. Cox-Fernandes. 2005. Dimorfismo sexual em Siluriformes e Gymnotiformes (Ostariophysi) da Amazônia. Acta Amazonica, 35(1): 97-110.

Reay, P. J. 1989. Reproductive tactics: a non-event in aquaculture?. Pp. 291-309. In: Potts, G. W. \& M. N. Wootton (Eds.). Fish reproduction: strategies and tactics. London, Academic Press, 410p.

Santos, E. P. 1978. Dinâmica de populações aplicada à pesca e piscicultura. São Paulo, Edusp, 129p.

Schwassmann, H. O. 1976. Ecology and taxonomic status of different geographic populations of Gymnorhamphichthys hypostomus, Ellis (Pisces, Cypriniformes, Gymnotoidei). Biotropica, 8: 25-40.

Silva, A., L. Quintana, J. L. Ardanaz \& O. Macadar. 2002. Environmental and hormonal influences upon EOD waveform in gymnotiform pulse fish. Journal of Physiology - Paris, 96: 473-484. 
Silva, A., L. Quintana, M. Galeano \& P. Errandonea. 2003. Biogeography and breeding in Gymnotiformes from Uruguay. Environmental Biology of Fishes, 66: 329-338.

Silva, A., L. Quintana, M. Galeano, P. Errandonea \& O. Macadar. 1999. Water temperature sensitivity of EOD waveform in Brachyhypopomus pinnicaudatus. Journal of Comparative Physiology A, 185: 187-197.

Suzuki, H. I. \& A. A. Agostinho. 1997. Reprodução de peixes do reservatório de Segredo. Pp. 163-181. In: Agostinho, A. A. \& L. C. Gomes (Eds.). Reservatório de Segredo: Bases ecológicas para o manejo. Maringá, Eduem, 387p.

Vazzoler, A. E. A. de M. 1996. Biologia da reprodução de peixes teleósteos: teoria e prática. Maringá, Editora da Universidade, $169 \mathrm{p}$.

Wooton, R. J. 1984. Introduction: tactics and strategies in fish reproduction. Pp. 1-12. In: Potts G. W. \& R. J. Wooton (Eds.). Fish reproduction: strategies and tactics. London, Academic Press, 410p.

Young, T. P. 1981. A general model of comparative fecundity of semelparous and iteroparous life histories. The American Naturalist, 118: 27-36.

Zar, J. H. 1999. Biostatistical analysis. New Jersey, Prentice-Hall, 663p.

Accepted October 17, 2009

Published December 18, 2009 